\title{
PERANCANGAN SISTEM INFORMASI PENCATATAN PEMBAYARAN SPP PADA PONDOK PESANTREN MODERN TGK CHIEK OEMAR DIYAN
}

\author{
Ubbaidillah $^{1}$, Evayani ${ }^{* 2}$ \\ ${ }^{1,2}$ Program Studi Akuntansi Fakultas Ekonomi Universitas Syiah Kuala \\ e-mail: ubaidillahdz18@gmail.com ${ }^{1}$, evayani@unsyiah.ac.id ${ }^{* 2}$
}

\section{* Corresponding Author}

\begin{abstract}
The development of technology today is very rapid and many innovations created such as administrative information systems have been used by many parties, both organizations and educational institutions. Especially in pesantren educational institutions that still use manual administrative information systems, therefore this study aims to assist the Administration in matters relating to the SPP payment process and SPP payment reports that are efficient and effective using desktops. This application is made with Xampp software and uses the PHP programming language that uses the System Development Life Cycle (SDLC) method. The results of the study were desktop-based SPP payment applications at the Tgk Chiek Oemar Diyan Modern Islamic Boarding School
\end{abstract}

Keywords: SPP Payment Application, SDLC, PHP

\section{Pendahuluan}

Sistem informasi terkomputerisasi memberikan sebuah gagasan yang dapat mempermudah untuk mengelola keseluruhan data sehingga terciptanya informasi lengkap dan akurat. Terciptanya informasi akurat setidaknya mengurangi permasalahan yang sering terjadi akibat kesalahan yang mungkin tidak diinginkan (Tri, 2014). Hal ini membuktikan bahwa perusahaan, instansi, organisasi, dan lembaga pendidikan memiliki mutu yang tinggi (Prakoso \& Herlawati, 2017).

\section{Berkembangnya}

teknologi

informasi

terkomputerisasi sangat diperlukan oleh dunia pendidikan terutama, dikarenakan dengan adanya hal tersebut dapat memudahkan pembelajaran dan juga manajemen sekolah. Maka dari itu, diharuskan pada bidang pendidikan untuk menerapkan teknologi informasi sehingga terwujudnya pendidikan yang lebih berkualitas (Harbiyanto, 2015).

Pesantren Tgk. Chiek Oemar Diyan yang berada di Indrapuri, merupakan salah satu lembaga pendidikan swasta yang berperan dalam melahirkan kader-kader penerus masa depan. Pada tahun ajaran 2018/2019 pesantren ini memiliki santri madrasah aliyah berjumlah 371 santri dan santri Madrasah Tsanawiyah berjumlah 696 orang santri. (sumber:serambinews.com, 11 Juni 2019). Jumlah santri yang mencapai 1.067 orang membuat proses administrasi yang dijalankan secara konvensional menjadi kurang efektif dan efisien.

Proses pencatatan yang masih menggunakan buku besar pada saat santri melakukan pembayaran SPP mengakibatkan proses pembayaran menghabiskan waktu yang lama, resiko kehilangan data, tingkat pengawasan yang relatif rendah dan adanya kesulitan dalam melakukan akses data pada saat pembuatan laporan keuangan. Data pembayaran yang semakin banyak mengakibatkan kesulitan pada bagian administrasi dalam melakukan pencarian data santri pada saat diperlukan dan membutuhkan waktu yang lama dalam melakukan rekapitulasi pembuatan laporan pembayaran SPP. Pencatatan yang masih manual juga dapat menimbulkan kesalahan dalam proses pencatatan, karena banyaknya proses transaksi pembayaran yang harus dilakukan pada setiap bulan. Oleh karena itu, perancangan sistem pembayaran SPP dapat membantu aktifitas pesantren pada proses pengolahan data khusus dalam segi pembayaran SPP.

\section{Kajian Pustaka}

\section{Sistem Informasi Akuntansi}

$$
\text { Maulinarhardi \& Advian (2013:1) }
$$

mendefinsiskan sistem infromasi akuntansi yakni pengoperasian dokumen atau catatan seperti jurnal 
laporan yang kemudian disajikana sedemikian rupa menjadi informasi yang dapat digunakan dalam sistem akuntansi proses pencatatan seluruh transaski harus menjadi manfaat dalam hal perencanaan dan pengendalian operasional bisnis.

Menurut Baridwan (2004:4) yang menjelaskan "suatu komponen yang mengumpulkan, menggolongkan, mengolah, menganalisis dan mengkombinasikan informasi keuangan yang relevan untuk pengambilan keputusan" merupakan arti dari sistem informasi akuntansi. Beberapa sub-sub baik fisik maupun nonfisik saling menyatu untuk pengelohan data yang terkait dengan permasalahan keuangan yang dengan hal itu menjadi informasi.

\section{Pengertian Sistem Informasi Pembayaran SPP Pengertian Sistem}

Menurut Ashari (2014) Mendefinisikan Sistem merupakan prosedur jaringan yang sesuai dengan pola yang telah dibuat untuk pelaksanaan tujuan organisasi termasuk menginput atau memproses data, sementara (Prakoso \& Herlawati, 2017) menjelaskan bahwa sistem adalah "jaringan yang memiliki hubungan bersama-sama untuk pelaksanaan kegiatan suatu sasaran tertentu.

\section{Tujuan Sistem}

Susanto (2013:23) mengungkapkan bahwa tujuan sistem adalah sasaran atau target akhir yang ingin diperoleh suatu sistem. Kriteria sasaran atau target harus diketahui terlebih dahulu agar target tersebut dapat tercapai, karena upaya tanpa mengetahui kriteria maka sasaran tersebut seharusnya dapat mencapai tergat yang diingikan untuk menilai seberapa besar keberhasilan yang telah didapat.

\section{Pengertian Informasi}

Menurut Jogiyanto (Menurut Jogiyanto (2008:692) informasi yakni hasil olahan dalam bentuk yang kebih berguna yang dapat menggambarkan kejadian yang sebenarnya. Menurut Soeherman \& Marion (2004:4) informasi yakni hasil data yang bernilai untuk disajikan dengan mudah sehingga tidak terlepat dari manusia atau dapat dikatakan sekumpulan data yang telah dikemas sehingga lebih mudah dipahami dan dimengerti.

\section{Sistem Informasi Pembayaran SPP}

Rochman, Sidik, \& Nazahah (2018) Mengemukakan, Sumbangan Penunjang Pendidikan (SPP) merupakan iuran yang pungut setiap bulan dari siswa di sekolah. Pembayaran SPP tersebut ditentukan berdasarkan kesepakatan rapat guru sekolah dan orang tua siswa.. Ashari (2014) mendefinisikan Sistem pembayaran digunakan untuk satu kegiatan atau usaha dalam mengatur semua kegiatan di sekolah.

\section{System Development Life Cycle}

Valacich, George, \& Hoffer, (2015:38) System Development Life Cycle (SDLC) merupakan metodologi yang digunakan untuk mengembangkan sistem dibanyak organisasi. SDLC memiliki empat tahapan standar dalam pengembangan sistem yang ada di organisasi, yaitu (1) kebijakan dan perencanaan sistem, (2) analisis sistem, (3) desain sistem, dan (4) implementasi dan operasi.

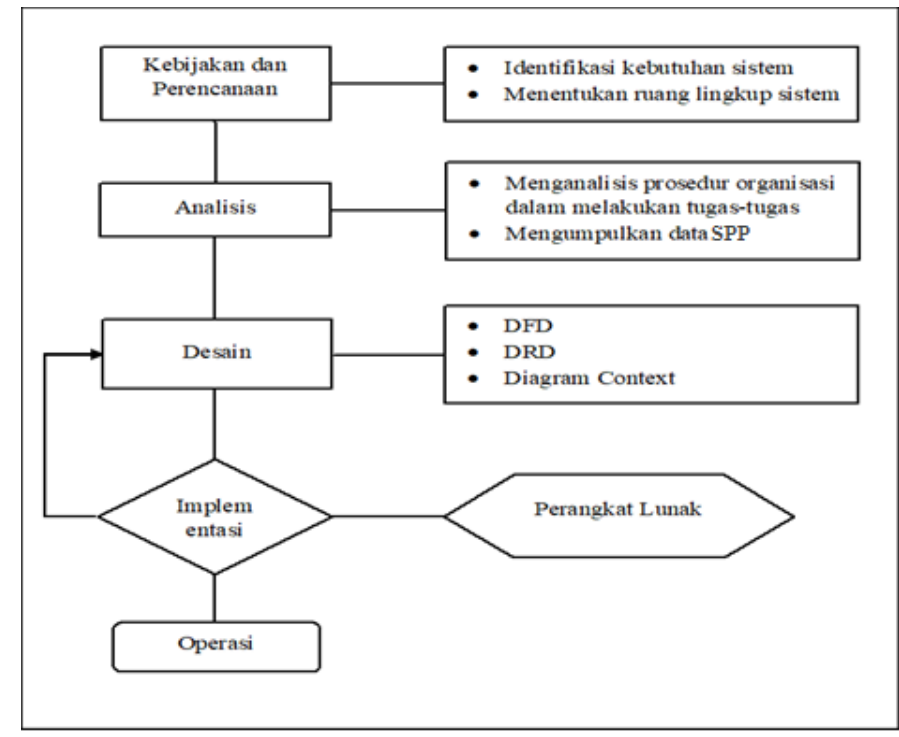

Sumber: Data diolah, 2019

\section{Gambar 1 Skema Perancangan Sistem}

\section{Metodologi Penelitia Desain Penelitian}

Desain penelitian adalah keseluruhan perencanaan dan kerangka kerja untuk menjawab tujuan penelitian yang akan memudahkan peneliti dalam melakukan penelitiannya. Desain penelitian merupakan cara mendapatkan data dengan tujuan dan kegunaan tertentu (Sugiyono, 2014).

Sekaran \& Bougie (2013:152) menjelaskan terdapat aspek-aspek dasar yang ada pada desain 
penelitian. Berikut uraian aspek-aspek dasar penelitian:

\section{1) Tujuan Studi}

Sebuah studi memiliki sifat eksploratif, deskriptif dan pengujian hipotesis. Hal tersebut tergantung pada seberapa besar penulis mengetahui tentang yang diteliti.

2) Situasi Studi

Situasi studi pada penelitian ini merupakan situasi tidak diatur. Penelitian ini dapat dilakukan dalam lingkungan yang alami, dimana pekerja berproses secara normal.

3) Unit Analisis

Unit analisis yang digunakan dalam penelitian adalah Organisasi, yaitu Pesantren Tgk. Chiek Oemar Diyan pada Kecamatan Indrapuri.

\section{Sumber dan Teknik Pengumpulan Data}

Sumber data pada penelitian ini merupakan data primer dan data sekunder. Data primer berasal dari wawancara dan observasi dan data sekunder ialah data dokumentasi. Cara pengumpulan data yang dilakukan dalam penelitian ini dengan dua cara, yaitu penelitian langsung ke lapangan dan studi kepustakaan.

\section{Metode Analisis Data}

Metode penelitian yang digunakan dalam penelitian ini adalah deskriptif kualitatif. Penelitian deskriptif merupakan metode yang digunakan untuk menggambarkan atau menganalisis suatu hasil penelitian tetapi tidak digunakan untuk membuat kesimpulan yang lebih luas (Sugiyono, 2014)

Berdasarkan definisi di atas penulis melakukan pengumpulan data yang berhubungan dengan pembayaran SPP pada Pesantren Modern Tgk Chiek Oemar Diyan. Selanjutnya dilakukan perancangan yang hasil akhirnya berbentuk software yang bisa digunakan dan dimanfaatkan.

Langkah-langkah yang harus dilakukan dalam rencana penelitian ini yaitu:

\section{1) Studi Pustaka}

Pada tahap ini dilakukan pengumpulan bahan pustaka sebagai acuan teori yang digunakan untuk mendefinisikan sistem informasi pembayaran SPP.
2) Perencanaan dan Analisis

Pada tahap perencanaan ini mulai membuat pengembangan sistem informasi pembayaran SPP pada Pesantren Modern Tgk Chiek Oemar Diyan. Pada tahap analisis sistem dilakukan terhadap sistem pembayaran SPP yang telah ada pada Pesantren Modern Tgk Chiek Oemar Diyan.

\section{3) Perancangan}

Membuat konsep perancangan berupa Flowmap dan diagram konteks proses. Untuk Flowchart proses yang sedang berjalan dan yang akan dirancang dapat dilihat pada Gambar 2. dan Gambar 3.

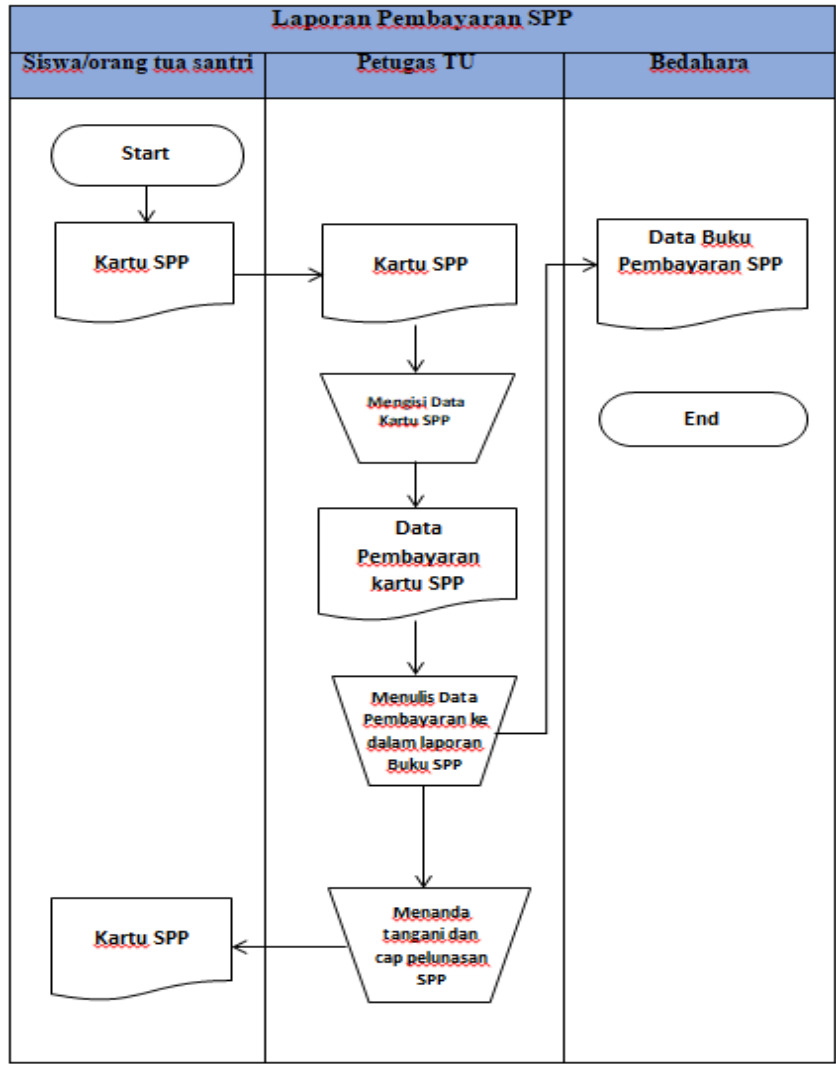

Sumber: Data diolah, 2019

Gambar 2. Flowchart Proses Pembayaran Yang Sedang Berjalan 


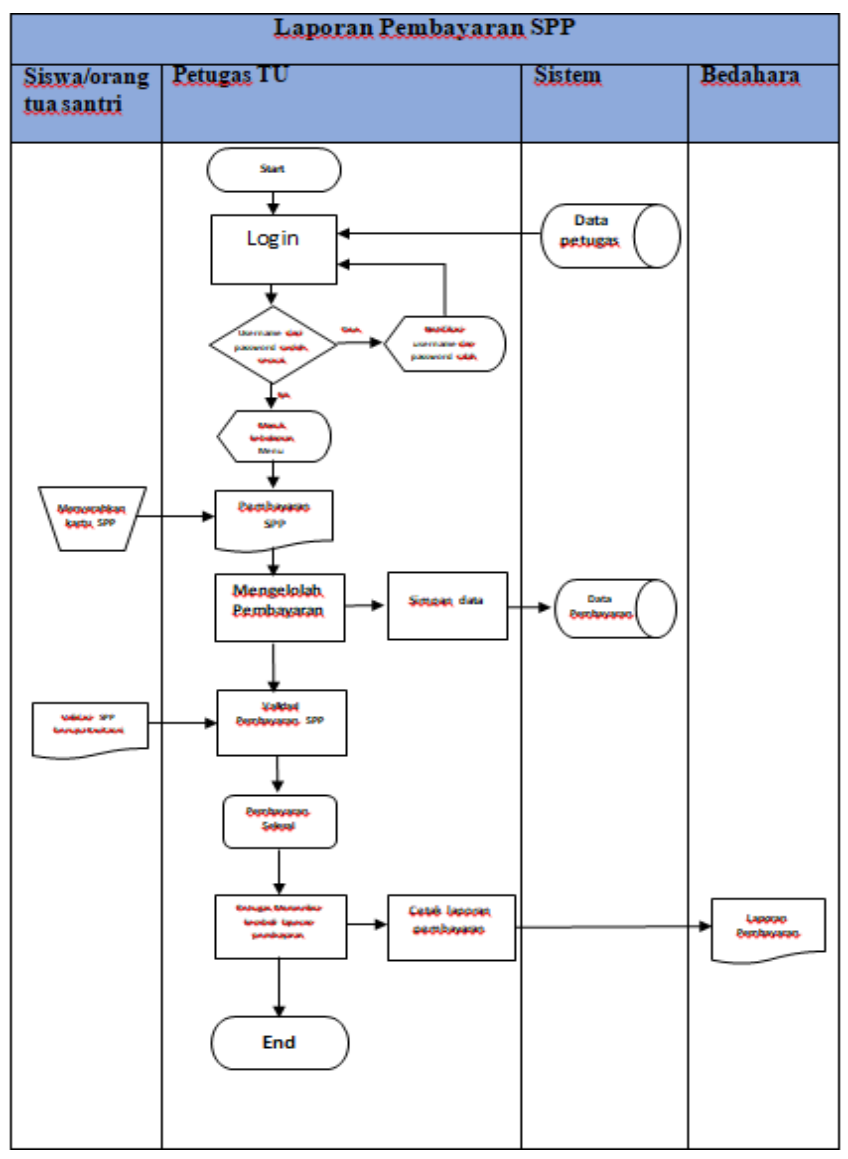

Sumber: Data diolah, 2019

\section{Gambar 3. Flowchart Proses Pembayaran Yang diusulkan}

4) Pengujian

Pada tahap pengujian ini terkait dengan perancangan, instalasi, dan rencana pemeliharaan. Dalam tahap ini akan dilakukan testing dan training dengan tujuan agar sistem dapat digunakan dengan baik.

5) Penggunaan

Tahap yang terakhir adalah tahap penggunaan dimana sistem sudah siap digunakan oleh penggunanya.

\section{Hasil Penelitian dan Pembahasan}

\section{Profil Pesantren Tgk Chiek Oemar Diyan}

Sejarah berdirinya Pesantren Modern Tgk. Chiek Oemar Diyan bermula dari kepedulian sosial seorang aktivis Muslim H. Sa'aduddin Djamal,SE (almarhum) yang melihat lembaga pendidikan di aceh belum mempunyai sebuah lembaga pendidikan pesantren terpadu khusus putri. Kepedulian bapak H. Sa'aduddin Djamal,SE (almarhum) mengundang beliau dan masyarakat untuk mendirikan sebuah pesantren terpadu khusus putri.

Seiring berjalannya waktu pada tahun $1990 \mathrm{H}$. Sa'aduddin Djamal,SE (almarhum) mendirikan pesantren terpadu khusus putri dengan memilih Putroe Krueng Lamkareung berdasarkan keinginan beliau pada awalnya yang dikhususkan untuk putri. Namun karena desakan dari masyarakat yang menginginkan santri putra juga diterima di pesantren Putroe Krueng Lamkareung, akhirnya nama Putroe krueng Lamkareung diubah menjadi Pesantren Tgk. Chiek Oemar Diyan (M. Ma'shum, Wawancara. 2020, Mei $31)$.

Pesantren Tgk. Chiek Oemar Diyan sendiri dipilih berdasarkan nama Ulama Besar Aceh Tgk. Chiek Oemar yang merupakan kakek buyut dari Bapak H. Sa'aduddin Djamal,SE (almarhum) sebagai pendiri pesantren ini, beliau merupakan keturunan dari Abu Lam U, karena lokasi pesantren terletak di Indrapuri maka diambillah nama Tgk. Chiek Oemar yang merupakan ayah dari Abu Lam U dan Abu Indrapuri yang lama menetap di kampung Yan Kedah Malaysia, untuk mengabadikan daerah dan tempat tinggal Tgk. Chiek Oemar maka diambillah nama Yan yang menjadi kombinasi dua kata Di Yan (Diyan) ((M. Ma'shum, Wawancara. 2020, Mei 31).

\section{Sumbangan Pembinaan Pendidikan Pesantren Tgk Chiek Oemar Diyan}

Pesantren Modern Tgk Chiek Oemar Diyan merupakan sebuah lembaga swasta yang bergerak di bidang pendidikan yang bersifat Boarding School, dalam peranannyan pesantren ini menetapkan Sumbangan Pembinaan Pendidikan (SPP) dari santriwan dan santriwati sebagai iuran biaya pendidikan dan biaya makan setiap bulanya. Biaya SPP normal selama 30 hari di Pesantren Modern Tgk Chiek Oemar Diyan berjumlah Rp 700.000, yang mana biaya ini dibagi menjadi dua kategori, yaitu biaya makan dan biaya pendidikan. Selain SPP bulanan Pesantren ini juga menetapkan SPP tahunan yang mana didalamnya terdapat biaya pembangunan yang berlaku bagi santri kelas Satu MTSS dan MAS, selanjutnya biaya listrik, kesehatan, kertas, ektraskulikuler, pemeliharaan, dan organisasi yang berlaku pada setiap santri selain santri kelas satu MTSS dan MAS (Wawancara: Fatimah, 31 Mei 2020). 


\section{Kebijakan dan Perencanaan Sistem}

Perancangan sistem pembayaran SPP pada Pesantren Modern Tgk. Chiek Oemar Diyan dimulai dengan tahap perencanaan dan menentukan poin penting dalam sistem yang nantinya akan dirancang. Pada tahap ini peneliti melakukan wawancara dengan bagian bendahara pesantren mengenai sistem pembayaran SPP yang sedang berjalan. Secara garis besar sistem yang berjalan masih menggunakan metode manual dengan mencatat di buku Administrasi Harian dan Bulanan Pesantren Tgk Chiek Oemar Diyan. Setelah melakukan wawancara, perancangan sistem pembayaran SPP dimulai dengan mengumpulkan beberapa dokumen yang digunakan untuk melengkapi proses penggunaan aplikasi pembayaran SPP, yaitu Gambar 4.2 berupa Buku Administrasi Harian Bulanan Pesantren Modern Tgk Chiek Oemar Diyan yang digunakan untuk mencatat pembayaran SPP santri pada saat santri membayar. Gambar 4 merupakan salah satu dokumen yang digunakan setiap kelas per-angkatan.

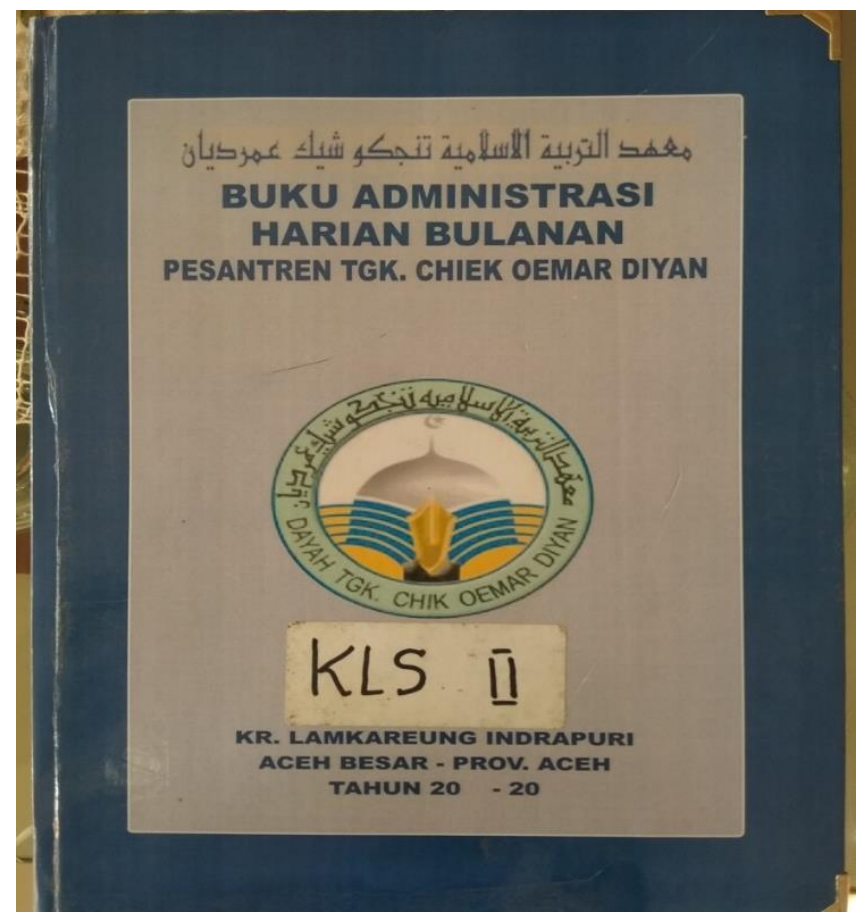

Sumber: Data diolah (2020)

\section{Gambar 4. Buku Administrasi Harian Bulanan}

\section{Analisis Sistem dan Prosedur Secara Manual Proses Pembayaran SPP}

Setelah mengumpulkan data yang diinginkan melalui wawancara dan observasi dengan bendahara Pesantren Modern Tgk Chiek Oemar Diyan, sistem pembayaran SPP pada Pesantren Modern Tgk Chiek Oemar Diyan menerapkan tahap-tahap untuk melakukan pembayaran SPP. Berikut adalah analisis tahapan yang telah berjalan pada Pesantren Modern Tgk Chiek Oemar Diyan.

1) Santri membayar SPP di bagian Bendahara Pesantren dengan menyerahkan kartu SPP dan uang tunai.

2) Bagian Bendahara mencatat pembayaran SPP dan melakukan Validasi kartu SPP.

3) Bendahara merekap data pembayaran SPP santri secara detail pada Gambar 4.5 Buku Rekapitulasi Administrasi Santri.

4) Bendahara merekap data pembayaran SPP santri pada buku Absen Uang Masuk Tahunan (Tahun Pelajaran 2019-2020)

\section{Diagram Konteks}

Berikut adalah diagram konteks yang menggambarkan bagaimana alur sistem pembayaran SPP yang saat ini berjalan secara umun di Pesantren Modern Tgk Chiek Oemar Diyan.

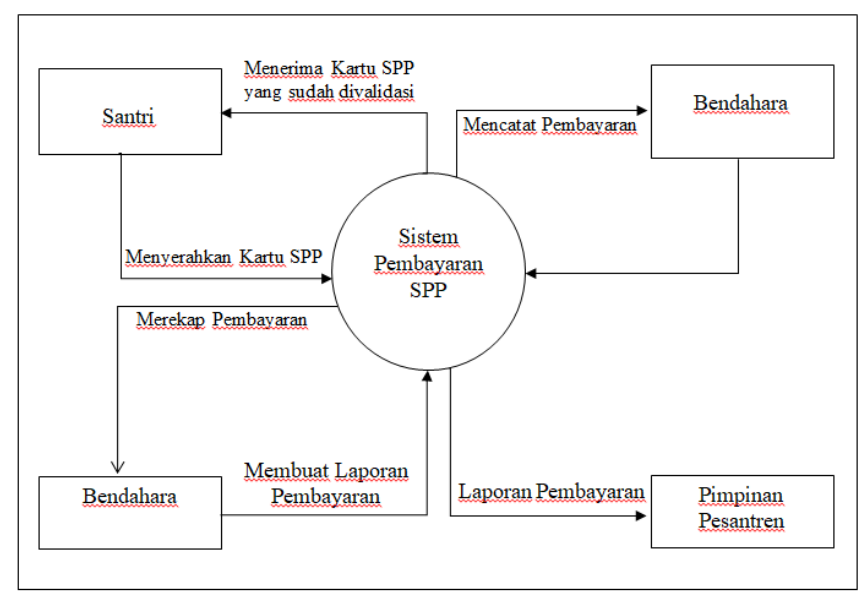

Sumber: Data diolah (2020)

\section{Gambar 5 Diagram Konteks}

\section{Diagram Arus Data}

Berikut adalah diagram alur data level 1 yang menggambarkan bagaimana alur sistem pembayaran SPP yang saat ini berjalan secara umum di Pesantren Modern Tgk Chiek Oemar Diyan. 


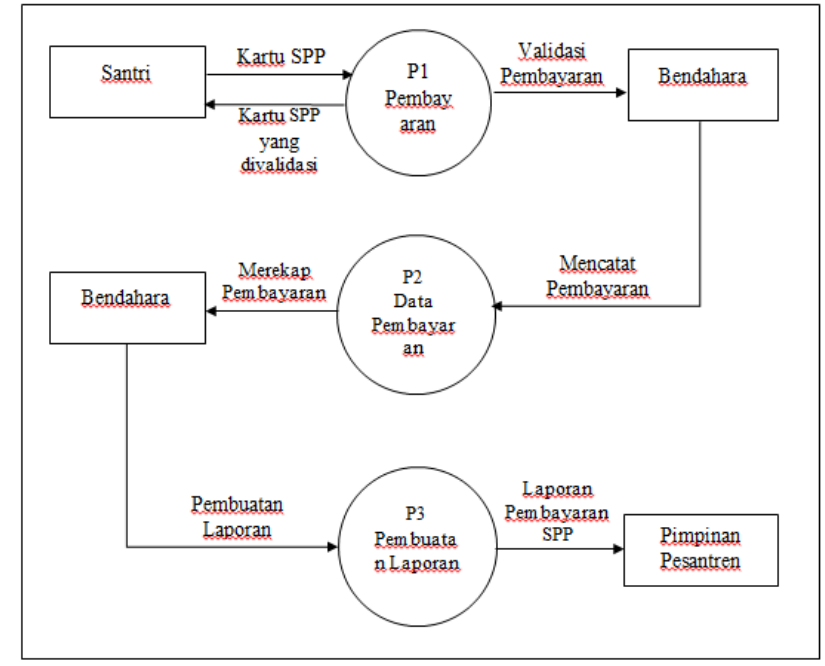

Sumber: Data diolah (2020)

\section{Gambar 6. Diagram Arus Data}

Pada diagram arus data Gambar 6 ini menjelaskan proses pembayaran SPP yang masih berjalan di Pondok Pesantren Modern Tgk Chiek Oemar Diyan. Berawal dari tahap santri melakukan pembayaran SPP dengan membawa kartu dan uang SPP untuk diberikan kepada bagian bendahara, bagian bendahara melakukan validasi pembayaran SPP di kartu SPP yang santri bawa dan menerima uang SPP. Setelah melakukan validasi kartu dan menerima uang pembayaran SPP, bagian bendahara mencatat pembayaran SPP pada Buku Administrasi Harian Bulanan santri. Pada tahap selanjutnya bagian bendahara melakukan rekapitulasi pembayaran SPP santri untuk setiap bulannya dan membuat laporan pembayaran SPP santri pada setiap akhir tahun ajaran yang berjalan. Setelah laporan siap dibuat pada akhir tahun ajaran bagian bendahara menyerahkan laporan pembayaran SPP kepada Pimpinan pesantren selaku pengambil keputusan tertinggi di pesantren Modern Tgk Chiek Oemar Diyan.

\section{Evaluasi Sistem yang Sedang Berjalan}

Menurut hasil dari pengamatan dan penelitian terhadap sistem informasi pembayaran SPP yang dilakukan di Pesantren Modern Tgk Chiek Oemar Diyan yang saat ini berjalan, maka sistem akan dievaluasi seperti pada table :
Tabel 1

Evaluasi Sistem yang Sedang Berjalan

\begin{tabular}{|c|c|c|}
\hline No. & Permasalahan & Solusi \\
\hline 1. & $\begin{array}{l}\text { Proses pencatatan pembayaran SPP } \\
\text { masih menggunakan sistem manual. }\end{array}$ & $\begin{array}{l}\text { Dengan adanya sistem informasi } \\
\text { pembayaran SPP, proses pencatatan dapat } \\
\text { dilakukan dengan cepat dan meminimalisir } \\
\text { terjadinya kesalahan pencatatan. }\end{array}$ \\
\hline 2. & $\begin{array}{l}\text { Proses pelaporan pembayaran SPP } \\
\text { yang masih menggunakan sistem } \\
\text { manual dengan merekap kembali data } \\
\text { pembayaran SPP santri. }\end{array}$ & $\begin{array}{l}\text { Dengan adanya sistem informasi } \\
\text { pembayaran SPP, proses pelaporan dapat } \\
\text { dilakukan secara langsung. }\end{array}$ \\
\hline 3 & Keamanan data masih belum terjamin. & $\begin{array}{l}\text { Adanya sistem informasi pembayaran SPP } \\
\text { menjamin keamanan data yang menjadi } \\
\text { lebih baik. }\end{array}$ \\
\hline
\end{tabular}

Sumber: Data Diolah(2020)

\section{Analisis Perancangan Sistem}

\section{Analisis Data}

Pesantren Modern Tgk Chiek Oemar Diyan memiliki masalah dalam membuat rekapitulasi untuk laporan pembayaran SPP karena Pesantren Modern Tgk Chiek Oemar Diyan masih menggunakan pencatatan manual. Proses pencatatan yang masih menggunakan buku administrasi harian bulanan seperti Gambar 4, disaat santri atau orang tua santri membayar SPP membuat proses rekapitulasi data menjadi kurang efektif.

\section{Analisis Penyimpanan Data}

Penyimpanan dokumen pembayaran SPP di Pesantren Modern Tgk Chiek Oemar Diyan yang digunakan saat ini berbentuk sebuah buku besar yang disimpan dilemari kantor Tata Usaha (TU) yang dipisahkan perkelas. Data akan sulit diakses jika penyimpanan data dilakukan dengan cara tersebut, proses akses data akan memakan waktu yang lama. Secara keamanan, data yang disimpan tidak aman dan dibutuhkan pengamanan yang lebih baik agar tidak hilang maupun rusak.

\section{Analisis Kebutuhan Sistem yang Diusulkan}

Kesimpulan yang dapat diambil dari permasalahan tersebut, Pesantren Modern Tgk Chiek Oemar Diyan membutuhkan suatu sistem informasi pembayaran SPP yang terkomputerisasi. Suatu sistem 
yang mudah dipahami oleh pihak bendahara Pesantren Modern Tgk Chiek Oemar Diyan untuk pembayaran SPP sehingga dapat menghasilkan informasi yang tepat dan meminimalisir terjadinya kesalahan dalam proses pencatatan pembayaran SPP. Sistem Informasi tersebut meliputi hal-hal berikut:

1) Tingkat keamanan dan kemudahan akses yang lebih terjamin dari sebelumnnya sehingga pihak yang terkait mampu mengakses informasi dengan cepat, aman dan kemudahan akses yang lebih terjamin dari sebelumnya.

2) Sistem yang dapat menyajikan data pembayaran SPP santri dengan akurat.

3) Sistem yang dapat menghasilkan laporan pembayaran SPP santri per-kelas dan per-jenis pembayaran.

\section{Perancangan Sistem}

Perancangan sistem adalah sebuah proses pengembangan sistem baru dari hasil yang direkomendasikan analisis sistem. Perancangan sistem dilihat dari apa saja yang dibutuhkan untuk memperbaiki kinerja bagian Administrasi. Perancangan sistem harus meliputi input, process, dan juga output dari yang diusulkan.

\section{Diagram Konteks yang Diusulkan}

Diagram konteks yang telah berjalan menunjukkan gambaran bagaimana alur sistem yang diusulkan secara rinci pada Pesantren Modern Tgk Chiek Oemar Diyan.

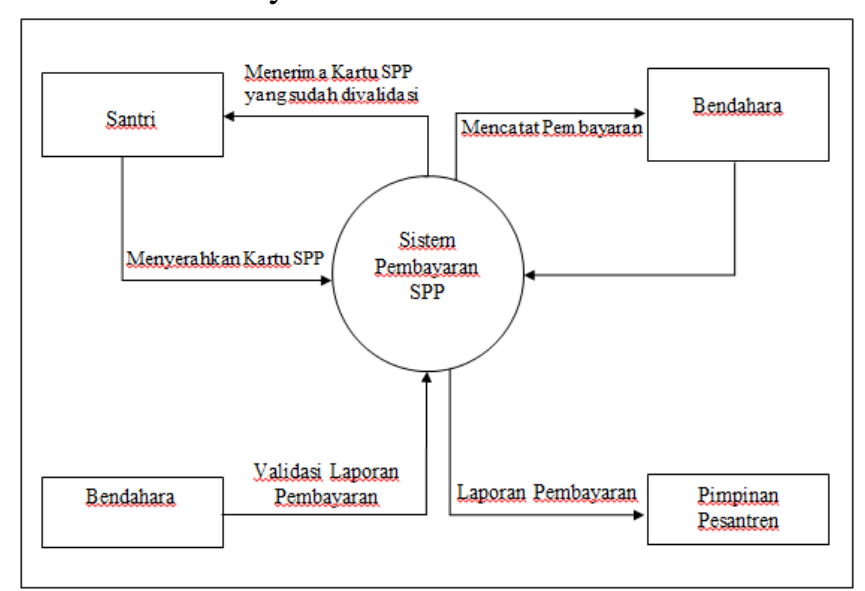

Sumber: Data diolah (2020)

Gambar 7. Diagram Konteks yang Diusulkan

\section{Diagram Arus Data yang Diusulkan}

Diagram Arus Data Level 1 memberikan gambaran alur sistem pembayaran SPP yang diusulkan secara rinci pada Pesantren Modern Tgk Chiek Oemar Diyan.

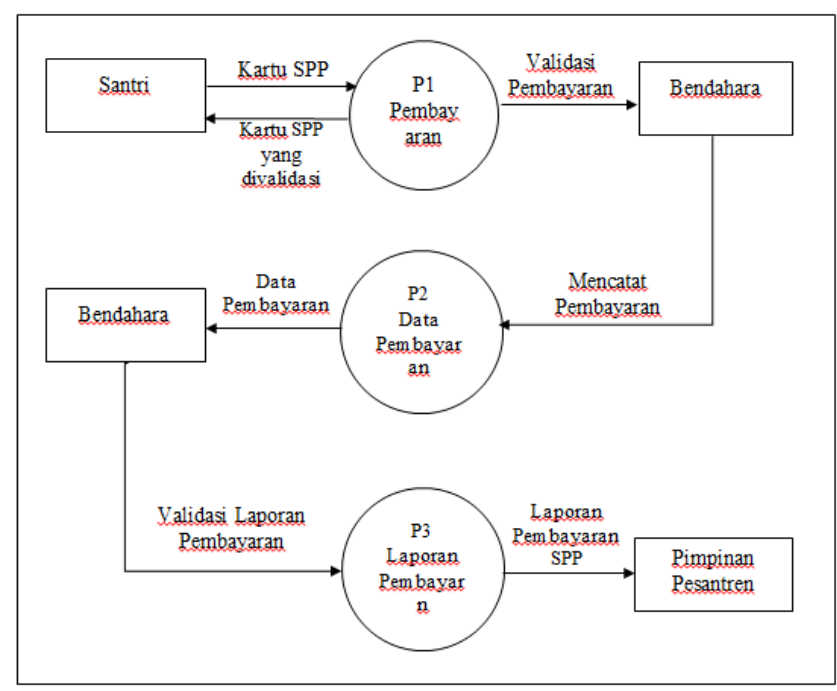

Sumber: Data diolah (2020)

\section{Gambar 8. Diagram Arus Data yang Diusulkan}

Diagram arus data yang diusulkan pada Gambar 8 diatas menjelaskan proses pembayaran SPP yang nantinya akan menggunakan sebuah Aplikasi pembayaran SPP yang dirancang. Pada tahap awal proses pembayaran, santri masih menggunakan kartu SPP sebagai pegangan untuk santri dan menjadi bukti pembayaran setelah kartu SPP divalidasi. Pada tahap ini santri membawa kartu dan uang SPP yang akan dibayar untuk di serahkan kepada bagian bendahara, selanjutnya bagian bendahara melakukan pencatatan atas pembayaran SPP pada sistem yang telah dirancang dan melakukan validasi pembayaran SPP pada kartu SPP santri secara manual. Setelah proses pencatatan dan validasi pembayaran selesai data pembayaran SPP langsung ter-input pada aplikasi pembayaran SPP yang sudah di gunakan. Selanjutnya bagian bendahara dapat melihat dan mencetak data laporan pembayaran SPP pada aplikasi yang sudah dirancang.

\section{Perancangan Basis Data yang Diusulkan}

Basis data yang akan dirancang adalah sistem pembayaran SPP. Basis data sistem pembayaran SPP berisi tentang pembayaran SPP secara 
terkomputerisasi dan laporan pembayaran SPP perbulan dan per-tahun.

Penelitian ini akan menjelaskan tentang aplikasi basis data pembayaran SPP lebih lanjut. Kamus data untuk basis data pembayaran SPP akan dijelaskan lebih rinci pada poin berikutnya.

\section{Kamus Data dan Uraian Proses}

Data dictionary atau kamus data dapat diuraikan sebagai data-data yang dibutuhkan dalam membangun suatu sistem. Kamus data diperlukan sebagai alat komunikasi untuk menilai informasi apa saja yang dibutuhkan oleh pengguna sehingga pembuat sistem dapat memenuhi kebutuhan pengguna. Kamus data mengenai perancangan sistem pembayaran SPP sesuai dengan berikut ini.

\section{Dokumen masukan}

a. Nama proses: $\log$ in

Tujuan : Masuk aplikasi

Penjelasan : Proses ini untuk memberikan hak akses bagi pengguna sistem yang mengetahui username dan password untuk masuk ke dalam sistem.

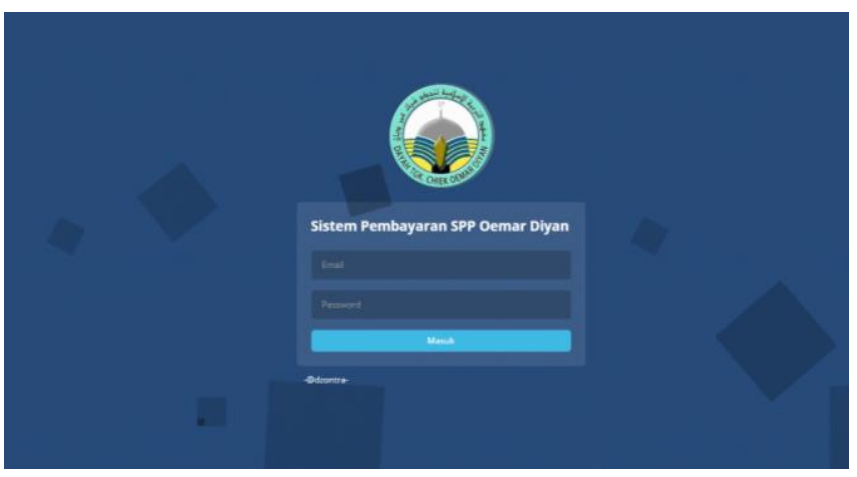

Sumber: Data Diolah (2020)

Gambar 9. Menu Log In

b. Nama proses : Data Santri.

Tujuan : Melihat data santri yang tersedia.

Penjelasan : Dengan menekan tombol "Data Master dan Santri" maka pengguna dapat melihat daftar data santri yang tersedia.

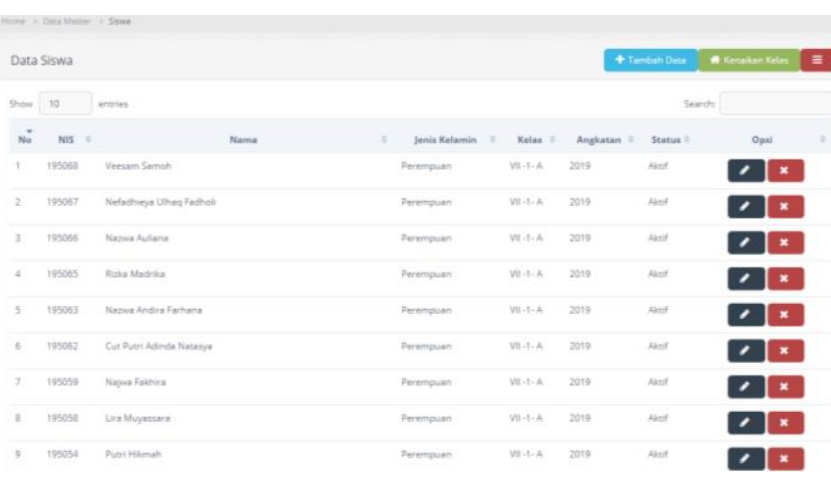

Sumber: Data Diolah (2020)

\section{Gambar 10 Menu Data Santri}

c. Nama proses : Form Input Nominal Pembayaran. Tujuan : Menentukan nominal pembayaran spp santri.

Penjelasan : Pada menu ini berfungsi untuk menentukan nominal pembayaran spp santri yang akan dibayar pada suatu periode.

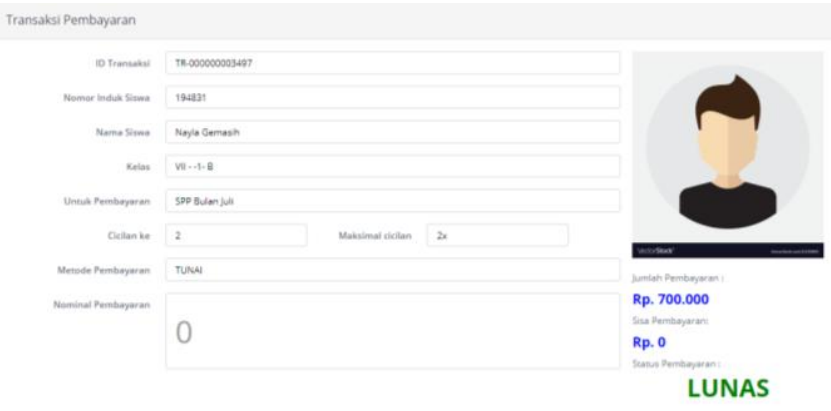

Sumber: Data Diolah (2020)

Gambar 11 Form Input Nominal Pembayaran

\section{Dokumen Keluaran}

a. Nama proses : Cetak Bukti Pembayaran.

Tujuan : Mencetak bukti pembayaran pada suatu periode.

Penjelasan : Pada menu ini berfungsi untuk mencetak bukti pembayaran pada suatu periode.

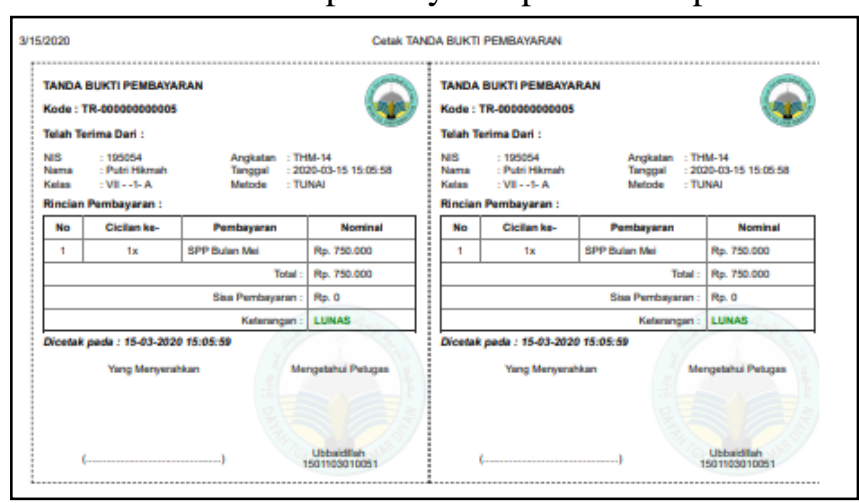

Sumber: Data Diolah (2020)

Gambar 12 Bukti Pembayaran 
b. Nama proses : Cetak Laporan Pembayaran.

Tujuan : Mencetak laporan pembayaran santri.

Penjelasan : Pada menu ini berfungsi untuk mencetak laporan pembayaran berdasarkan NIS, Nama Kelas, Jenjang Pendidikan, Angkatan, Jenis Pembayaran dan Status Pembayaran pada suatu periode.

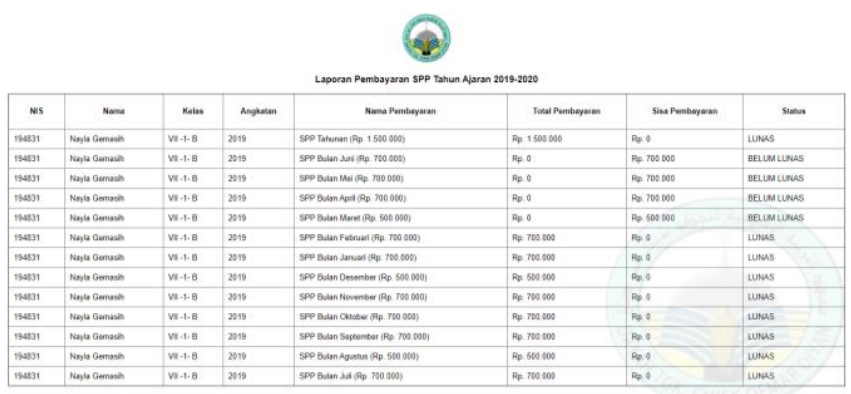

Sumber: Data Diolah (2020)

Gambar 13 Laporan Pembayaran SPP Per-NIS Santri

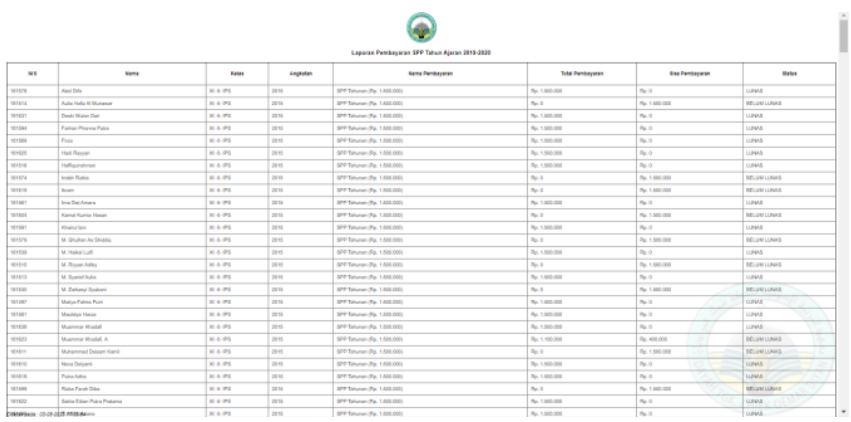

Sumber: Data Diolah (2020)

Gambar 13 Cetak Laporan Pembayaran SPP PerNama Kelas.

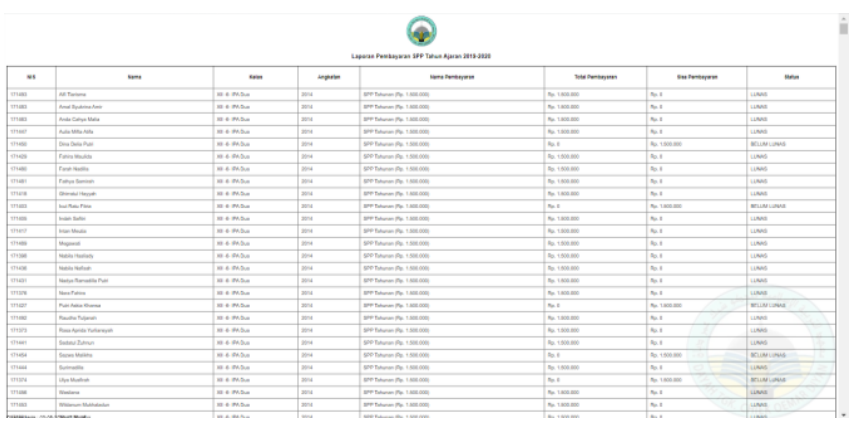

Sumber: Data Diolah (2020)

Gambar 14 Cetak Laporan Pembayaran SPP PerJenjang Pendidikan.

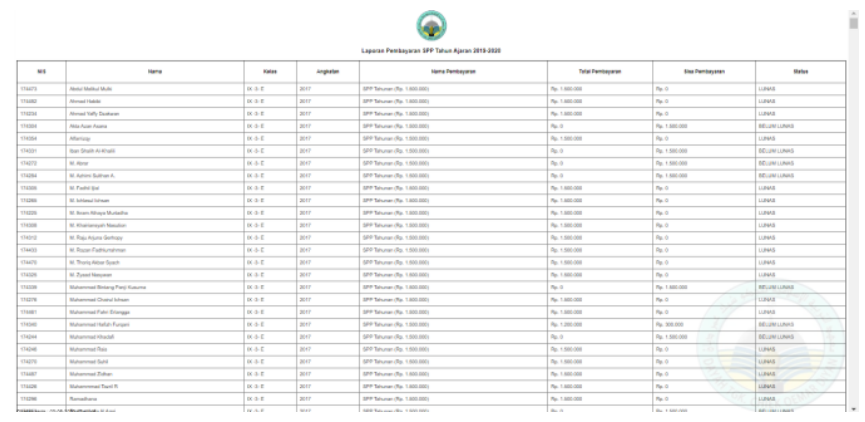

Sumber: Data Diolah (2020)

Gambar 15 Cetak Laporan Pembayaran SPP PerAngkatan.

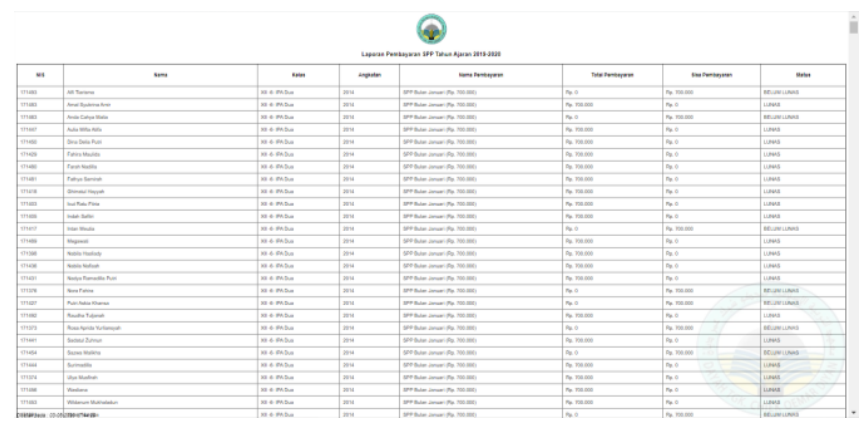

Sumber: Data Diolah (2020)

Gambar 16 Cetak Laporan Pembayaran SPP PerJenis Pembayaran.

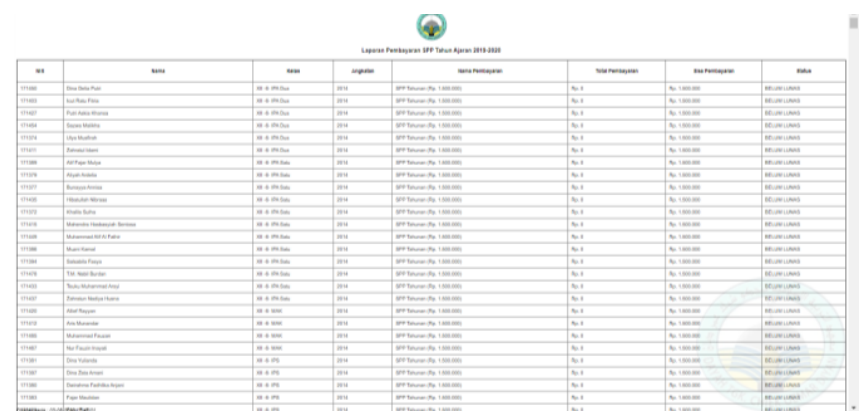

Sumber: Data Diolah (2020)

Gambar 17. Laporan Pembayaran SPP Per-Status Pembayaran

\section{Implementasi Sistem dan Pemeliharaan Sistem}

Tahap Implementasi sistem bertujuan untuk menilai apakah sistem yang telah dirancang berjalan dengan baik pada Pesantren Modern Tgk Chiek Oemar Diyan. Pada tahap ini sistem yang sudah dirancang akan diinstall pada perangkat komputer bagian bendahara pesantren Tgk. Chiek Oemar Diyan agar bisa dipelajari oleh bagian bendahara dan menganalisi kendala atau kekurangan sistem seperti kemampuan kinerja sistem dalam menghasilkan output yang sesuai dengan kebutuhan Pesantren. 
Pengujian kinerja sistem yang dilakukan pada Pesantren Modern Tgk Chiek Oemar Diyan dilakukan dengan cara menginput informasi pembayaran SPP santri ke dalam sistem yang telah dirancang. Informasi yang dimasukkan berupa biodata santri, jenis pembayaran SPP dan data kelas santri yang mana informasi tersebut akan ter-input dalam proses transaksi pembayaran yaitu Nomor Induk Santri, Nama Santri, Kelas, Jenis Pembayaran dan Nominal Pembayaran.

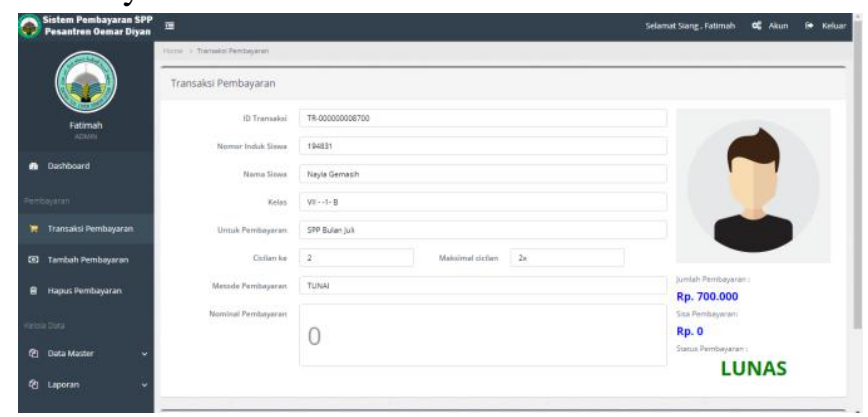

Sumber: Data Diolah (2020)

\section{Gambar 18 Form Pembayaran}

Setelah transaksi pembayaran selesai, maka sistem akan langsung membawa data transaksi ke laporan pembayaran SPP yaitu NIS, nama santri, kelas, jenjang pendidikan, jenis pembayaran, total pembayaran, dan status pembayaran secara otomatis dan real-time.

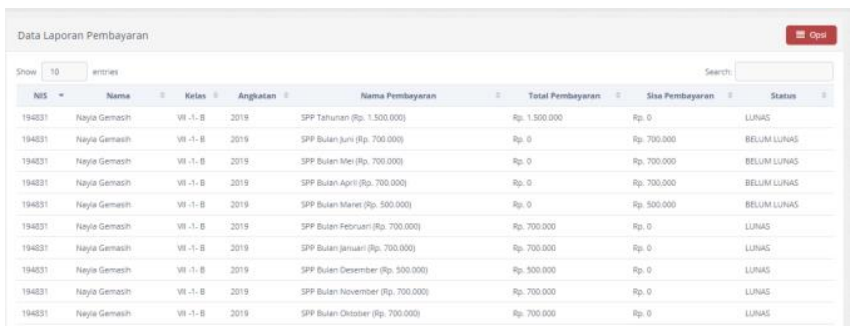

Sumber: Data Diolah (2020)

\section{Gambar 19 Laporan Pembayaran}

\section{Operasi Sistem}

Setelah tahap Implementasi dan pengujian kinerja sistem secara umum telah dilakukan, selanjutnya programmer melakukan pelatihan dan pengawasan dalam pengoperasian sistem tingkat lanjut yang mana bagian bendahara menerapkan proses pembayaran SPP secara terkomputerisasi pada Madrasah Aliyah terlebih dahulu, dengan tujuan mempermudah bagian bendahara beradaptasi dalam pengoperasian sistem karena santri madrasah aliyah yang masih berjumlah 371 santri dibandingankan santri Madrasah Tsanawiyah yang berjumlah 696 orang santri. Setelah bagian bendahara mempelajari proses pembayaran dengan cara terkomputersasi, maka selanjutnya melakukan pemeliharan sistem dan memperbaiki apabila dalam pengoperasian sistem terjadi masalah dengan tujuan agar sistem dapat digunakan secara maksimal oleh bagian bendahara.

Menurut hasil pengujian dan penerapan sistem pembayaran SPP yang telah dijalankan, dapat ditarik kesimpulan bahwa sistem pencatatan pembayaran SPP yang dirancang dapat berfungsi dengan baik pada Pesantren Modern Tgk Chiek Oemar Diyan. Sistem yang dirancang digunakan oleh bagian bendahara pesantren selaku bagian yang mengelola pembayaran SPP, untuk akses sistem pembayaran SPP hanya diberikan kepada bagian bendahara.

Penerapan sistem pada Pesantren Modern Tgk Chiek Oemar Diyan sangat membantu dalam proses pembayaran SPP sehingga berdampak pada meningkatnya tata administrasi pembayaran SPP menjadi lebih baik, dimana pembayaran SPP menjadi lebih efisien, efektif, dan akurat sehingga dapat meminimalisir terjadinya kesalahan dalam pencatatan pembayaran SPP.

\section{Kesimpulan}

Setelah melakukan penelitian dan menerapkan sistem pada Pesantren Modern Tgk Chiek Oemar Diyan, kesimpulan yang dapat diambil yaitu:

1. Perancangan sistem informasi pembayaran SPP pada Pesantren Modern Tgk. Chiek Oemar Diyan dapat menghasilkan data input dan output, dimana data santri yang sudah dimasukan dalam sistem menjadi data input bagi pihak pesantren. Selanjutnya data output dari aplikasi yang sudah dirancang merupakan laporan pembayaran yang dapat di akses dengan beberapa pilihan yaitu berdasarkan NIS, nama kelas, angkatan, jenis pembayaran dan status pembayaran Santri.

2. Perancangan sistem informasi pembayaran SPP dapat menghasilkan informasi yang lebih baik, akurat dan terpercaya.

3. Perancangan sistem informasi pembayaran SPP dapat mennyimpan data dengan aman dan mempermudah pihak bendahara dalam mengakses data pembayaran santri saat diperlukan. 


\section{Daftar Pustaka}

Ashari, A. 2014. Sistem Informasi Pembayaran Sumbangan Pembinaan Pendidikan (SPP) pada Sekolah Menengah Atas Negeri 2 Pacitan. Indonesian Journal on Networking and Security, $3(3), 65-70$.

Baridwan, Zaki. 2004. Intermadiate Accounting, Edisi Kedelapan. Yogyakarta: BPFE

Harbiyanto, Denis. 2015. Sistem Informasi Pembayaran Sekolah Berbasis Sms Gateway Di Smk Bhinneka Karya 1 Boyolali. Yogyakarta: Pogram Gelar Sarjana Universitas Negeri Yogyakarta.

Jogiyanto, H. 2008. Metodologi Penelitian Sistem Informasi. Yogyakarta: Andi offset

Maulinarhardi, Ranatarisza, M. \& Advian, Noor, M. 2013. SISTEM INFORMASI AKUNTANSI: Aplikasi pada Administrasi Bisnis. Malang: Elektronik Pertama dan Terbesar di Indonesia.

Prakoso, M. D., \& Herlawati. 2017. Sistem Informasi Pembayaran Biaya Pendidikan Siswa Pada SMK Perwira Bangsa Bekasi Utara. Bina Insani ICT ,4(1), 95-110. Rochman

Rochman, A., Sidik, A., \& Nazahah, N. 2018. Perancangan Sistem Informasi Administrasi Pembayaran SPP Siswa Berbasis Web di SMK Al - Amanah. Jurnal SISFOTEK Global, 8(1), 51-56.

Sekaran, U., \& Bougie, R. 2013. Research Methods for Business: A SkillBuilding Approach. USA: Wiley.

Soeherman, Bonnie \& Pinontoan, Marion. 2008. Designing Information System. Jakarta: PT Elex Media Komputindo.

Sugiyono. 2014. Metode Penelitian Kuantitatif, Kualitatif, dan Kombinasi (Mixed Methods). Bandung: Alfabeta.

Susanto, Azhar. 2013. Sistem Informasi Akuntansi. Jakarta: Gramedia.

Tri, S. 2014. Sistem Informasi Pencatatan Pembayaran Uang Sekolah Berbasis Multiuser. Jurnal Mahasiswa STEKOM Semarang, 1-9.
Valacich, J. S., George, J. F., \& Hoffer, J. A. 2015. Essentials of Systems Analysis and Design. England: Pearson Education Limited. 